\title{
The Effect of Smartphone Addiction on Adolescent Mental Health and Social Interaction
}

\author{
Muhammad Faridl Alwi \\ Department of Public Health \\ Science Sports Science Faculty \\ State University of Malang \\ Malang, Indonesia \\ faridlalwi26@gmail.com
}

\author{
Sapto Adi \\ Sports Science Faculty \\ State University of Malang \\ Malang, Indonesia \\ sapto.adi.fik@um.ac.id
}

\author{
Windi Chusniah Rachmawati \\ Department of Public Health \\ Science \\ Sports Science Faculty \\ State University of Malang \\ Malang, Indonesia \\ windi.rahmawati.fik@um.ac.id
}

\begin{abstract}
Excessive use of smartphones will cause a person to become addicted. Smartphone addiction is a condition where a person has a tendency to use a smartphone continuously and does not pay attention to the negative impacts it can cause. A person who is addicted to a smartphone will feel happy when using a smartphone, then feel stressed and anxious when he cannot meet his needs for using a smartphone. Someone who is addicted to smartphones will spend a lot of time using smartphones. Adolescence is a period of transition from childhood to adulthood. A person who enters adolescence will experience physical, emotionaly and cognitive changes. Activities that are often carried out will greatly affect the development of adolescents, including the use of smartphones. The purpose of this study was to determine the effect of smartphone addiction on mental health and adolescent social interactions. The research design used using the literature review method. The database used for literature searches uses Google Scholar, Springer and Proquest. For literature selection using PRISMA Flow Diagram and at the stage of literature quality assessment using JBI Critical Appraisal Tools. The results obtained as many as six literatures were obtained after going through selection in accordance with the research criteria. Three articles related to mental health and three other articles related to social interactions. The conclusion of this study is that smartphone addiction has an impact on adolescent mental health, especially anxiety and depression. Addiction to smartphones also affects adolescent social interactions.
\end{abstract}

Keywords- Smartphone Addiction, Mental Health, Social Interaction, Adolescent

\section{INTRODUCTION}

Based on research data from O'Dea (2020) shows that the number of smartphone users in the world reached 3.2 billion people in 2019 and is estimated to increase to 3.5 billion people in 2020. While in Indonesia the number of smartphone users reached $63 \%$ in 2019. in 2019 and is expected to increase to $70.05 \%$ in 2020 (Muller, 2020).

The ICT survey conducted by the Ministry of Communication and Information (Kemenkominfo) RI in 2017 stated that as many as $65.34 \%$ of the Indonesian population aged 9-19 years already had a smartphone (Kemenkominfo RI, 2017). The usual activities when using a smartphone are communicating, entertainment (games, videos, and music), studying and working. The frequency of smartphone use in the 9-19 year age group is mostly around 1-3 hours of use, which is $34.51 \%$ (Kemenkominfo RI, 2017). In another study conducted by Chaidirman, dkk. (2019) shows that teenagers spend 5-12 hours using smartphones, the applications they often play are online games. In addition to online games, social media is also one of the smartphone features that cause teenagers to become addicted (Mar'ah et al., 2020). A survey was conducted on 589 Bruneian respondents, the results obtained as many as two-thirds of respondents using smartphones more than 6 hours per day, and $46 \%$ of respondents stated that they could not live without a smartphone (Anshari et al., 2016).

Smartphones offer several conveniences in our lives, but we also need to be aware of the negative impacts of smartphone use, the most concerning of which is smartphone addiction. Smartphone addiction is a phenomenon related to uncontrolled smartphone use (Cha and Seo, 2018). Specifically, adolescents are a high-risk group for smartphone addiction. Teenagers are very attached to their smartphones, and they think of smartphones as their second selves. Many smartphone users have reported that they would 
not be able to live without a smartphone (Wajcman, Bittman and Jones, 2007).

Excessive use of smartphones will cause a person to become addicted. Smartphone addiction according to Mulyati dan NRH, (2018) is a condition in which a person has a dependency or tendency to use smartphones continuously and ignores the negative impacts that can be caused. Someone who is addicted to a smartphone will feel happy when using a smartphone, then feel stressed and anxious when he can't meet the needs of using his smartphone.

Someone who is addicted to smartphones will spend a lot of time using a smartphone. Adolescence is a period of transition of a person from childhood to adulthood. A person who enters adolescence will experience physical, emotional and cognitive changes. Activities that are often carried out will greatly affect the development of adolescents, including the use of smartphones. Based on the explanation above, the writer wants to examine the effect of smartphone addiction on mental health and adolescent social interaction.

\section{RESEARCH METHODS}

This study uses a literature review method. The database used for literature searches using Google Scholar, Springer and Proquest. For the selection of literature using PRISMA Flow Diagrams and at the stage of assessing the quality of the literature using JBI Critical Appraisal Tools. The inclusion criteria used in this study are: literature in the form of journals, theses, theses and dissertations; the year of publication of the literature in the last 10 years; speak Indonesian or English; the literature is comprehensively accessible; in the form of research articles; quantitative research design. And the exclusion criteria in this study are: literature in the form of literature review research results and the literature can only be accessed partially

\section{RESULT}

The literature obtained from the entire database was 4,241 literatures/articles, 2180 articles from Google Scholar, 692 literatures from Springer Link, and 1078 literatures from Proquest. The final results of the literature obtained after going through the screening process using PRISMA Flow Diagrams were 6 literatures.

The following are the results of the literature quality assessment from 6 studies that have been obtained using the JBI Critical Appraisal Checklist:

TABLE I. STUDY QUALITY ANALYSIS RESULTS

\begin{tabular}{|c|l|c|}
\hline No. & \multicolumn{1}{|c|}{ Study } & Assessment Result \\
\hline 1. & $\begin{array}{l}\text { (Amalya, Tarigan and Sadikin, } \\
2019)\end{array}$ & Included \\
\hline
\end{tabular}

\begin{tabular}{|c|l|c|}
\hline No. & \multicolumn{1}{|c|}{ Study } & Assessment Result \\
\hline 2. & (Kim et al., 2019) & Included \\
\hline 3. & (Primadiana et al., 2019) & Included \\
\hline 4. & $\begin{array}{l}\text { (Rahmadani and Widiastuti, } \\
2018)\end{array}$ & Included \\
\hline 5. & $\begin{array}{l}\text { (Supriatno and Romadhon, } \\
2017)\end{array}$ & Included \\
\hline 6. & (Wahyuningsih, 2017) & Included \\
\hline
\end{tabular}

Based on 6 literatures that have been selected, 3 articles discuss the impact of smartphones on adolescent mental health and 3 articles discuss the impact of smartphones on adolescent social interactions. An article that discusses the impact of smartphone addiction on adolescent mental health, namely research from (Amalya, Tarigan and Sadikin, 2019; Kim et al., 2019; Primadiana et al., 2019), and for research that discusses smartphone addiction behavior on adolescent social interactions, namely research conducted by (Supriatno and Romadhon, 2017; Wahyuningsih, 2017; Rahmadani and Widiastuti, 2018).

The results of data analysis are presented in the form of a table containing information about the author, title, year of publication, research objectives, methods, research samples and research results. The following are the results of data analysis of 6 selected articles: (Tabel 2.)

\section{DISCUSSION}

\section{A. The Effect of Smartphone Addiction on Adolescent Mental Health}

In research conducted by Amalya et al., (2019) In a study conducted by the number of respondents who experienced smartphone addiction as many as 59\% of respondents had a high level of smartphone addiction, in another study conducted by Primadiana et al., (2019), explained that the level of smartphone addiction was in the respondents as much as $50 \%$. However, this number is quite different from the number of respondents' addiction levels in research conducted by S. G. Kim et al., (2019), in a study conducted in South Korea only $7.5 \%$ of the total respondents. While it is difficult to interpret this variation given the lack of existing literature investigating the prevalence of smartphone addiction across different regions, a meta-analysis of internet addiction also found significant variation in prevalence ranging from $0.6 \%$ in Italy to $26.7 \%$ in Hong Kong. using a variety of assessment tools and boundary values (Hwang, Shon and Choi, 2011). Thus, the variation in the current literature regarding the prevalence of smartphone addiction may be due to inconsistent study methods, study samples, and geographic variations. 
The three studies that discussed the influence of smartphone addiction on adolescent mental health both showed that there was a significant relationship between smartphone use and adolescent mental health (Amalya, Tarigan and Sadikin, 2019; Kim et al., 2019; Primadiana et al., 2019). However, in a study conducted by Amalya et al., (2019) only describes mental health conditions in general, does not explain specifically what types of mental health are associated with adolescent smartphone addiction. In contrast to the previously described study, Primadiana et al., (2019) explained specifically that the mental health studied was about social anxiety. Adolescence is a period where mental and social maturity has not yet been achieved. A person when in the adolescent phase experiences physical and psychological changes in him. Emotional development that is still relatively unstable makes teenagers tend to be anxious about their interlocutor, he is afraid of bad judgment from the interlocutor against him. Teenagers who are addicted to smartphones tend to withdraw more often from social interactions, this is not good for adolescent development. Adolescents need social interaction so that they can learn and can achieve mental and social maturity. In line with these studies, in other studies related to mental health, (Kim et al., 2019) specifically describes mental health related to smartphone addiction in adolescents, namely anxiety and depression.

\section{B. The Effect of Smartphone Addiction on Adolescent Social Interaction}

Research conducted by Supriatno \& Romadhon, (2017), explained that the use of smartphones affects the social interaction of adolescents. In line with this research, Rahmadani \& Widiastuti, (2018) explained that smartphone use is related to adolescent social interaction, the higher the use of smartphones will be inversely proportional to the lower social interaction in adolescents. Not different from the two studies described previously, the research conducted by Wahyuningsih, (2017) explained that the intensity of smartphone use was positively related to adolescent antisocial behavior. The higher the intensity of smartphone use, the higher the antisocial behavior in adolescents. However, in addition to the negative impact, research conducted by Supriatno \& Romadhon, (2017) also explained about the positive impact of using smartphones, namely being able to communicate with their study group friends.

Students often use smartphones during free time that should be used to interact with friends or the surrounding environment. They usually use smartphones during school breaks, hang out with friends, when at home, and at bedtime. Various features in smartphones make teenagers spend more time using smartphones. Teenagers use smartphones in general to play games, social media, chat and search for information through a web browser. 


\begin{tabular}{|c|c|c|c|c|c|c|}
\hline 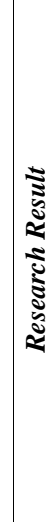 & 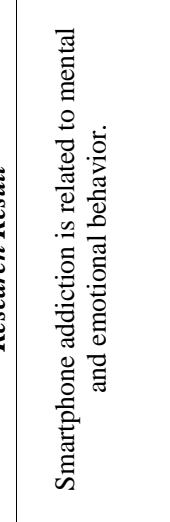 & 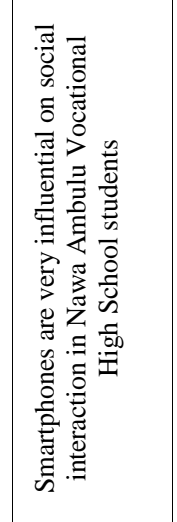 & 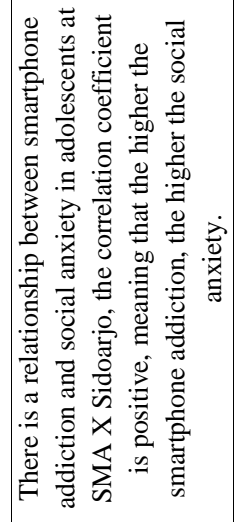 & 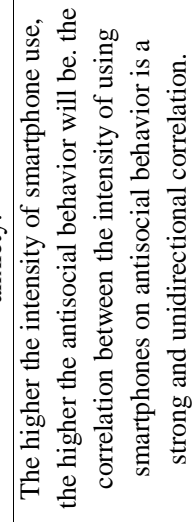 & 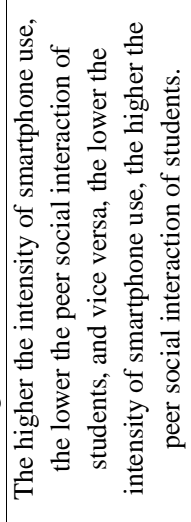 & 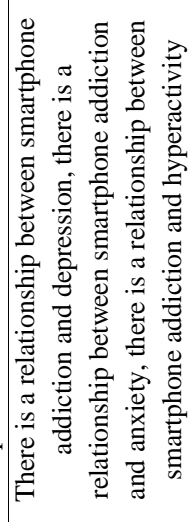 \\
\hline 䛌 & 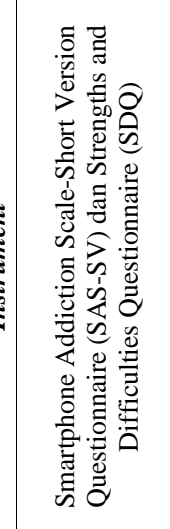 & 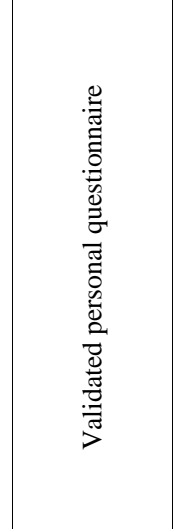 & 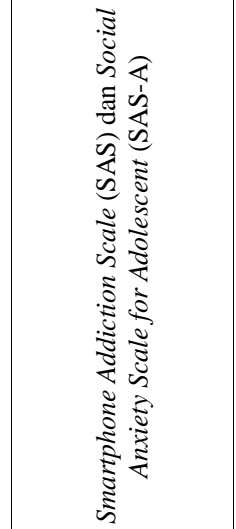 & 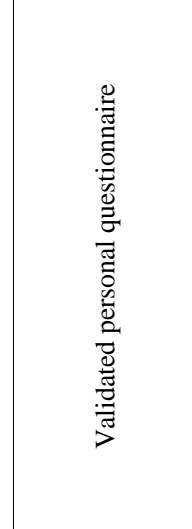 & 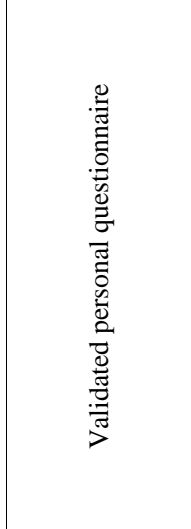 & 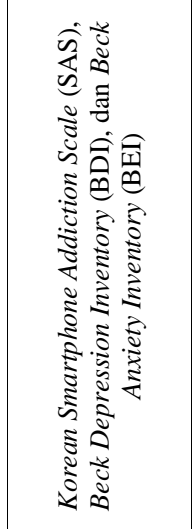 \\
\hline ఫ్ & 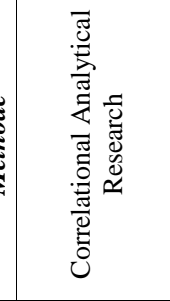 & 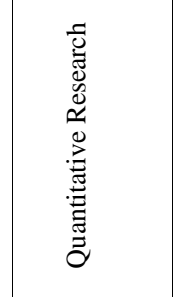 & 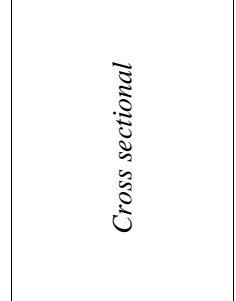 & 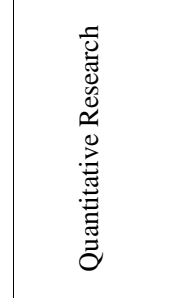 & 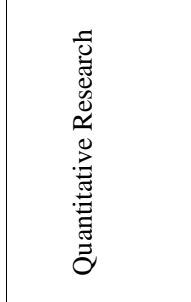 & 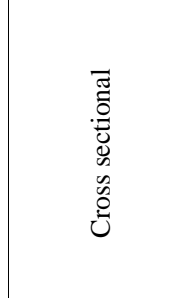 \\
\hline & 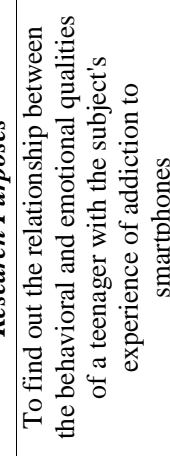 & 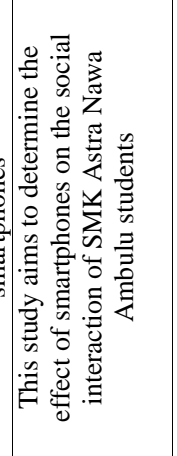 & 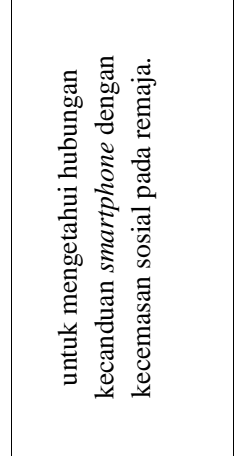 & 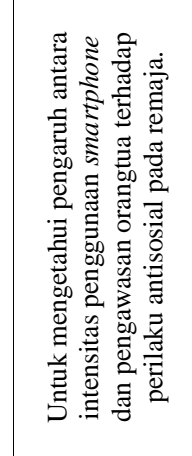 & 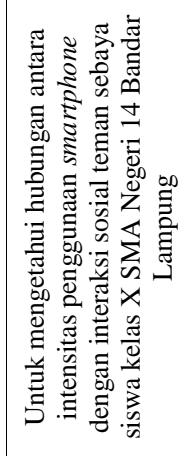 & 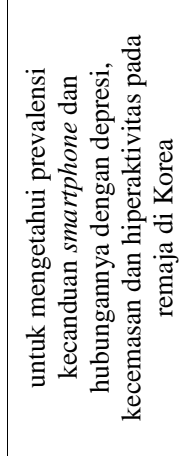 \\
\hline 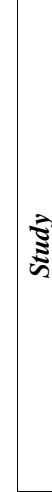 & 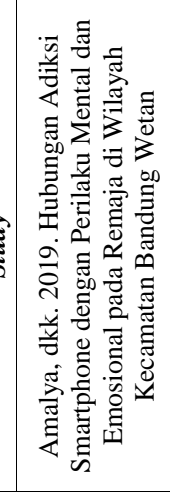 & 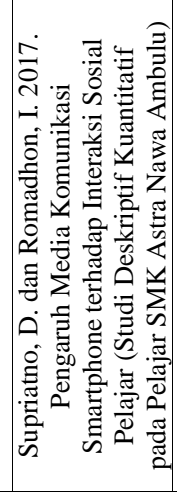 & 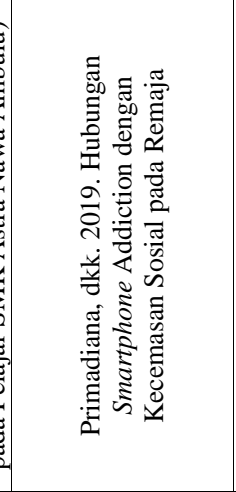 & 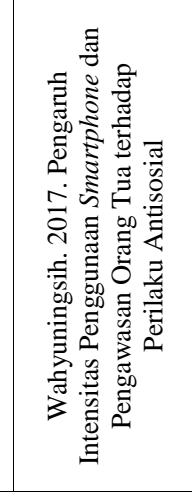 & 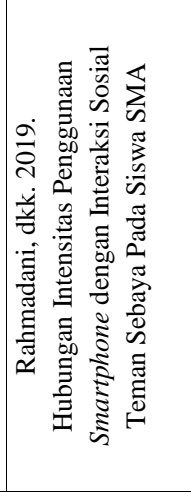 & 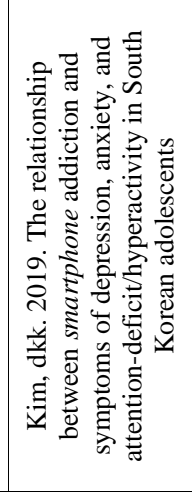 \\
\hline & - & $i$ & $m$ & $\dot{+}$ & in & 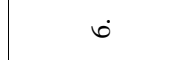 \\
\hline
\end{tabular}




\section{CONCLUSION}

\section{A. Conclusion}

Addiction to smartphones affects the mental health of adolescents, in this case the health of adolescents who are affected are anxiety and depression. Someone who is addicted to smartphones will feel anxiety about bad judgment by others.

Addiction to smartphones also affects adolescents social interactions, the negative impact obtained is that the higher the use of smartphones, the lower the social interaction among adolescents, but besides that there is also a positive impact, namely being able to communicate with their group friends.

\section{B. Suggestions}

Parents are expected to provide more supervision for their children. Moreover, during the pandemic, children use smartphones more often for online learning. parental control is needed so that children do not overdo it and abuse their smartphones.

There is a need for research with a wider scope to determine the negative impact of smartphone addiction in other aspects, so that it can be used as material for planning intervention programs for the harmful effects of smartphone addiction.

\section{REFERENCES}

[1] Amalya, F. P., Tarigan, R. and Sadikin, H. (2019) 'Hubungan Adiksi Smartphone dengan Perilaku Mental dan Emosional pada Remaja di Wilayah Kecamatan Bandung Wetan', Journal Kedokteran Nanggroe Medika, 2(2), pp. 917. Available http://jknamed.com/jknamed/article/view/59.

[2] Anshari, M. et al. (2016) 'Smartphone habit and behavior in Brunei: Personalization, gender, and generation gap', Computers in Human Behavior. Elsevier Ltd, 64, pp. 719727. doi: 10.1016/j.chb.2016.07.063.

[3] Cha, S. S. and Seo, B. K. (2018) 'Smartphone use and smartphone addiction in middle school students in Korea: Prevalence, social networking service, and game use', Health Psychology Open, 5(1). doi: 10.1177/2055102918755046.

[4] Chaidirman, Indriastuti, D. and Narmi (2019) 'Fenomena Kecanduan Penggunaan Gawai ( Gadget ) pada Kalangan Remaja Suku Bajo', Journal of Holistic Nursing and Health Science, 2(2), pp. 33-41. doi https://doi.org/10.14710/hnhs.2.2.2019.33-41

[5] Hwang, H. S., Shon, S. H. and Choi, Y. J. (2011) 'Exploring Factors Affecting Smart-phone Addiction-Characteristics of Users and Fuctional Atributes', Korean Journal of
Broadcasting and Telecommunication Studies, 25(2), pp. 277-313. Available at: https://scholar.google.co.id/scholar?hl=id\&as_sdt=0\%2C5\& $\mathrm{q}=.+$ Exploring+factors+affecting+smart-phone+addiction-ch aracteristics+of+users+and+functional+attribute $\& b \operatorname{bnG}=$ (Accessed: 16 December 2020).

[6] KEMENKOMINFO RI (2017) Survey Penggunaan TIK 2017. Jakarta.

[7] Kim, S. G. et al. (2019) 'The relationship between smartphone addiction and symptoms of depression, anxiety, and attention-deficit/hyperactivity in South Korean adolescents', Annals of General Psychiatry. BioMed Central, 18(1), pp. 1-8. doi: 10.1186/s12991-019-0224-8.

[8] Mar'ah, E. M., Istianah, N. and Qona'ah, A. (2020) 'The Correlation between Intensity of Smartphone Usage with Social Media Addiction, Fear of Missing Out, and Need for Touch among Adolescents', International Journal of Psychosocial Rehabilitation, Volume 24, pp. 856-862. doi: 10.37200/IJPR/V24I9/PR290105

[9] Muller, J. (2020) Smartphone penetration rate as share of the population in Indonesia from 2015 to 2025*. Available at: https://www.statista.com/statistics/321485/smartphoneuser-penetration-in-indonesia/.

[10] Mulyati, T. and NRH, F. (2018) 'Kecanduan Smartphone Ditinjau Dari Kontrol Diri Dan Jenis Kelamin Pada Siswa Sma Mardisiswa Semarang', Empati, 7(4), pp. 152-161.

[11] O’Dea, S. (2020) Smartphone users worldwide 2016-2021. Available at: https://www.statista.com/statistics/330695/number-ofsmartphone-users-worldwide/.

[12] Primadiana, D. B. et al. (2019) 'Hubungan Smartphone Addiction dengan Kecemasan Sosial Pada Remaja', ejournal Unair, 1(1), pp. 21-28. Available at: http://ejournal.unair.ac.id/PNJ\%7C21JournalHomepage:https://ejournal.unair.ac.id/PMNJ/index.

[13] Rahmadani, K. and Widiastuti, R. (2018) 'Hubungan Intensitas Penggunaan Smartphone dengan Interaksi Sosial Teman Sebaya Pada Siswa SMA', jurnal Universitas Lampung: Procedia Sosial Behavioral Sciences Turkish, 9(1), pp. 1-16.

[14] Supriatno, D. and Romadhon, I. (2017) 'Pengaruh Media Komunikasi Smartphone Terhadap Interaksi Sosial Pelajar (Studi Deskriptif Kuantitatif pada Pelajar SMK Astra Nawa Ambulu)', Paradigma Madani, 4(2), pp. 65-74.

[15] Wahyuningsih, D. (2017) 'Pengaruh Intensitas Penggunaan Smartphone Dan Pengawasan Orangtua Terhadap Perilaku Antisosial', pp. 1-12.

[16] Wajcman, J., Bittman, M. and Jones, P. (2007) The Impact of The Mobile Phone on Work/Life Balance. 